Original Research Paper

\title{
Relational Contracting in the Building Sector in Jordan as a Substitute to Conventional Formal Methods
}

\author{
${ }^{1}$ Razan Aleasawi and ${ }^{2}$ Sultan Tarawneh \\ ${ }^{I}$ Civil Engineering, Jordan University, Amman, Jordan \\ ${ }^{2}$ Dean of Faculty of Engineering, Civil Engineering Mutah University, Al-Karak, Jordan
}

Article history

Received: 26-12-2019

Revised: 04-03-2020

Accepted: 21-03-2020

Corresponding Author:

Razan Aleasawi

Civil Engineering, Jordan

University, Amman, Jordan

Email: razan.h.issawi@gmail.com

\begin{abstract}
The socioeconomic policies within the Hashemite Kingdom of Jordan aim to enhance the Public-Private Partnership (PPP), one of the Relational Contracting models, to encourage investment, improve public services, upgrade infrastructure and boost financial resources, in line with Jordan 2025 Vision (Ministry of Municipal Affairs, 2014). The construction sector itself has a growth plan of $5 \%$ in order to meet this vision, however, it suffers many difficulties. This paper aims to highlight one of the main problems (i.e., wrong choice of the contracting model) that causes a significant effect on the project as well as create a practical project management tool that supports the decision-making process at the concept stage of projects in Jordan. The project context (internal and external factors) has been linked to different parts of the contracting model; contract forms, compensation forms and co-operation forms "Fig. 1". The aim is to find the relationship between each factor within every part of the contracting model. Consequently, identify how all these relationships could affect the process of selecting the cooperation form, between the owner and the contractor(s). Semistructured interviews with parties who have actual experience with relational contracting in the Jordanian construction sector have been conducted. The main findings of this research led to the creation of a project management tool that supports the decision-making process at the concept stage of projects in Jordan, regarding relational contracting. These findings suggest that relational contracting is the right choice for complex projects within the context of critical resources, critical resources and lead-time and uncertainties.
\end{abstract}

Keywords: Relational Contracting, Contracting Model, PPP, Project Management, Jordan

\section{Introduction}

The construction sector in Jordan is considered to be one of the most significant contributing sectors to the national economy. However, it suffers from many difficulties which affect its capability to support the economy efficiently (Ministry of Municipal Affairs, 2014). In 2012, the estimated volume of work in construction in both public and private sectors reached 1,158 million JD which came second only to the trade sector. This revenue represents $13.35 \%$ of the total contribution from all economic sectors (DS, 2013). Most construction projects suffer from delays and cost overrun. Research conducted on infrastructure projects in Jordan from 2000 to 2008 (Al-Hazim et al., 2017) found that there are large differences between the estimated and actual cost of the projects, which ranged from $101 \%-600 \%$, with an average cost overrun of $214 \%$.
The study also showed that the time delay for projects was between $125 \%-455 \%$, with $226 \%$ on average.

These delays and cost overruns are considered a significant barrier to the profitability and growth of the construction industry in Jordan. Especially given that, to achieve the targeted macro-economic plan of 5\% growth in Jordan's GDP (from 2018-2022), the growth of the construction sector must reach 15\% (Council, 2017).

The Jordanian government suggested that the construction sector should introduce new international best practices and develop procedures for submitting tenders as a remedy for barriers to profitability and growth in this sector (DS, 2013). In construction, the fragmented nature of the industry that has led to unsatisfactory performance in the past, acted as a catalyst for researchers to begin exploring the potential of these approaches. One of the most promising is Relational 
Contracting (RC) (Rahman and Kumaraswamy, 2004; Palaneeswaran et al., 2003).

Theories that emphasize the benefits of close, long-term relationships among different organizations are receiving increasing attention throughout the academic literature (Faisol et al., 2005). Many terms have been used to describe relationship phenomena such as relationship quality, cooperative relationships, RC, strategic alliances and teamworking (Faisol et al., 2005).

A Public-Private Partnership (PPP) is a type of relational contract whose effectiveness is based upon a relationship of trust between the parties. This is a sociolegal philosophy that requires all project participants to belong to a single (project) organization (Rahman and Kumaraswamy, 2004). RC represents a core element of mutual cooperation and team-working (Rahman and Kumaraswamy, 2004) and has the potential to provide contractual flexibility, improve relationships and build team-working (MacNeil, 1974; 1980). Thus, PPP is a facilitating process that allows the government to initiate a project that has public sector defined goals and well-stated performance indicators to be monitored accordingly, while the private sector funds and operates the project based on a set of contractual agreements (Sawalha, 2015). PPPs help make the most of scarce public funding and introduce private-sector technology and innovation to provide better-quality public services through improved operational efficiency (Sawalha, 2015).

Abbasi et al. (2005) suggested that there should be new laws governing cooperation with different parties in the industry to make new tools with new legislation to protect the rights of all parties. The study also recommended merging small companies to make larger and stronger ones, this should benefit all parties by limiting the intense competitions in the market.

The problems in the construction industry caused by contractual arrangements, in which the construction process operates, include uncertainty, fragmentation of the construction supply chain and the opposing relationships between clients and contractors. This leads to the loss of many opportunities to achieve a win-win situation where all parties are sharing risks and rewards (Kawawu, 2005).

During the last two decades, governments around the world in both developed and developing countries started considering PPPs, mainly as a means of reforming the public sector (Al-Shqairat et al., 2014). Developing countries, for example Lebanon, adopted PPPs in several fields to enhance the growth of private sector activity by participating in infrastructure, manufacturing and services, such as telecommunications and energy sectors (Jamali, 2004).

$\mathrm{RC}$ as a contracting model which enhances cooperation and innovation and it is well established in many parts of the world. However, there is a need to customize this approach to reflect the characteristics of the construction sector in Jordan. The most important factors or context affecting the suitability of the contracting model are: Project type (level of complexity) (Williamson, 1979), the market condition for bidding, the lead-time for the project (Campbell and Harris, 2005) and uncertainties which might mean the design and/or requirements through the execution stage of the project will need to be changed (Williamson, 1985).

The contracting model itself has three interacting components which are: The contract form (the distribution of responsibilities between the client (owner) and the contractor(s)), compensation form (how the contractor(s) is compensated) and governance structure (how the co-operation or governance of a project is structurally organized).

In this research, these three components have been studied in a different project context and semi-structured interviews have been conducted with different owners, contractors and consultants who have experience in an $\mathrm{RC}$ project. The findings of this research contribute to the development of the practice in the construction sector as it introduces a practical project management tool that supports the decision-making process at the concept stage of projects in Jordan.

\section{Related Literature}

\section{Transaction Cost Economics (TCE) Theory}

Transaction Cost Economics (TCE) is essential to this study because it links economic and sociological viewpoints on Industrial Corporation and their contractual relations. This theory concentrates on the costs included in making transactions instead of producing products. It highlights the factors with direct dealings. For each transaction, transaction cost depends on three critical dimensions: (1) Asset specificity, (2) uncertainty, (3) frequency of transactions (Williamson, 1979).

High levels of uncertainty tied with asset specificity, or measurement difficulty, make contracting risky (Williamson, 1985). For example, if there are no suitable protections in a contract, under high uncertainty situations, a contractor may disapprove of making specialized asset investments. Under such mixtures of risks, individuals and organizations might choose one of the following strategies:

- Vertically integrate

- Change the exchange to the short-term

TCE theory supports that vertical integration (partnerships) has access to better information disclosure and different incentive mechanisms may deal more effectively with such mixtures of risks (Williamson, 1985). 
TCE suggests that the three principal rules considered in any decisions on a given governance mechanism are:

- The 'bounded rationality' of the different parties to the contract. This assumption means that although any party to a contract plans to be rational, his intellectual abilities are limited and cannot always plan and monitor perfectly

- Information is usually unequally distributed. So, parties to a contract have access to partial, imbalanced and/or imperfect information

- Contract parties may act in their own self-interest or may tend to be opportunistic

Based on these three assumptions, TCE focuses on minimizing the opportunism and assist in reducing transaction costs by clearly considering the efficiency effects of adopting alternative types of governance in transactions.

\section{Questionnaire Design}

The contract types used in construction projects define the features of cooperation and coordination between project stockholders. (Macneil R. I., 1978) has proposed three kinds of contracts. These are; classical form (the most popular), neo-classical form (which has some flexibility compared to the classical one) and the relational form (which depends on the partnerships between the project parties, those parties are usually public and private, i.e., PPPs).

From a TCE perspective, an optimal contract is one which has been made with minimal cost but delivers the desired quantity, price and quality of the supplier's product or service. Therefore, to create a practical tool to help choose the best contracting model for different projects in Jordan, a semistructural questionnaire was designed. The aim was to find the effect of the factors on selecting the best contract for the project, taking into consideration the internal and external factors (market situation, regulations, level of project complexity, time and uncertainty) and including the three interacting parts of any contracting model which are:

- The contracting forms: Construction Management, Design-Bid-Built and Design-Build

- The compensation forms: Fixed Price, Reimbursable Cost and Reimbursable Cost with Incentives

- The co-operation forms: Classical Contracting, NeoClassical Contracting and Relational Contracting

Figure 1 illustrates the impact that factors have on the project content and then, on the contract model. Therefore, the process of designing the contract model should take into consideration the main factors affecting the project content to achieve the minimal cost and deliver the required quantity, price and quality.

For every type of project (non-complex, semicomplex, complex) and different characteristics of project context there is a total of 18 combinations, as shown in "Table 1".

To study the effect of the factors on the contracting model, the questionnaire looked at the interaction between each project type and all the characteristics and each characteristic with the other. Figure 2 illustrates the interaction between the external and internal factors and project type that were used in the questionnaire scenarios.

For example, the following scenario was assumed in the questionnaire: A complex project type in a low market situation, with project characteristics of (resources critical, enough time, high level of uncertainty). Based on this assumed scenario, respondents must choose the best contract form, compensation form and cooperation form, as shown in Fig. 3.

Thus, 17 more scenarios were answered and the number of answers in each category was evaluated using Excel as a percentage of the total number of the answers for every single project context from the 26 respondents.

The respondents choose which combination of contract form, cooperation form and compensation form are most recommendable, based on the project type and characteristics in that situation. The questionnaire targeted practitioners and owners who had experience in $\mathrm{RC}$ in addition to other contracts in the country, from both the public and private sector, including foreign and local contractors and consultants, as well as clients including government officials ("Table 2").

The projects mentioned in "Table 3" are directly correlated to this research concept since they apply the RC method.

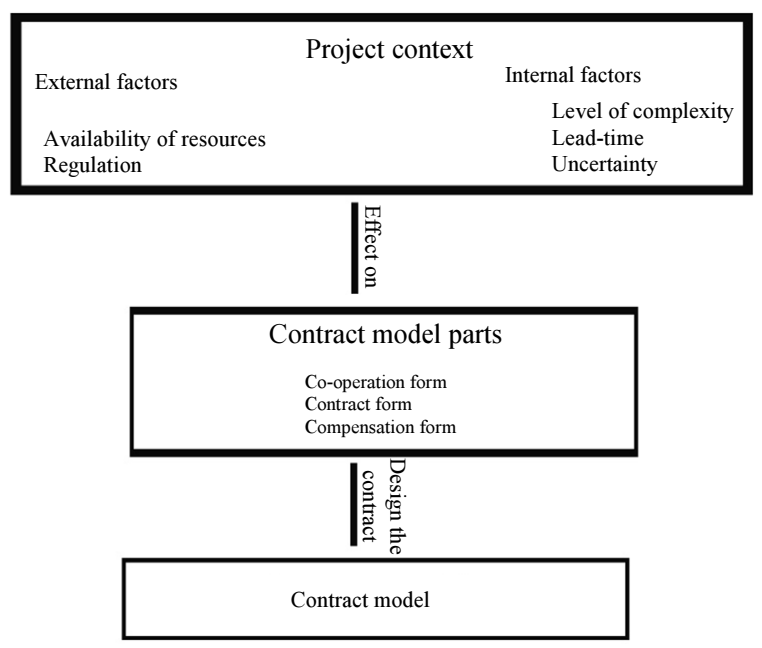

Fig. 1: The effect of factors on the contract model 


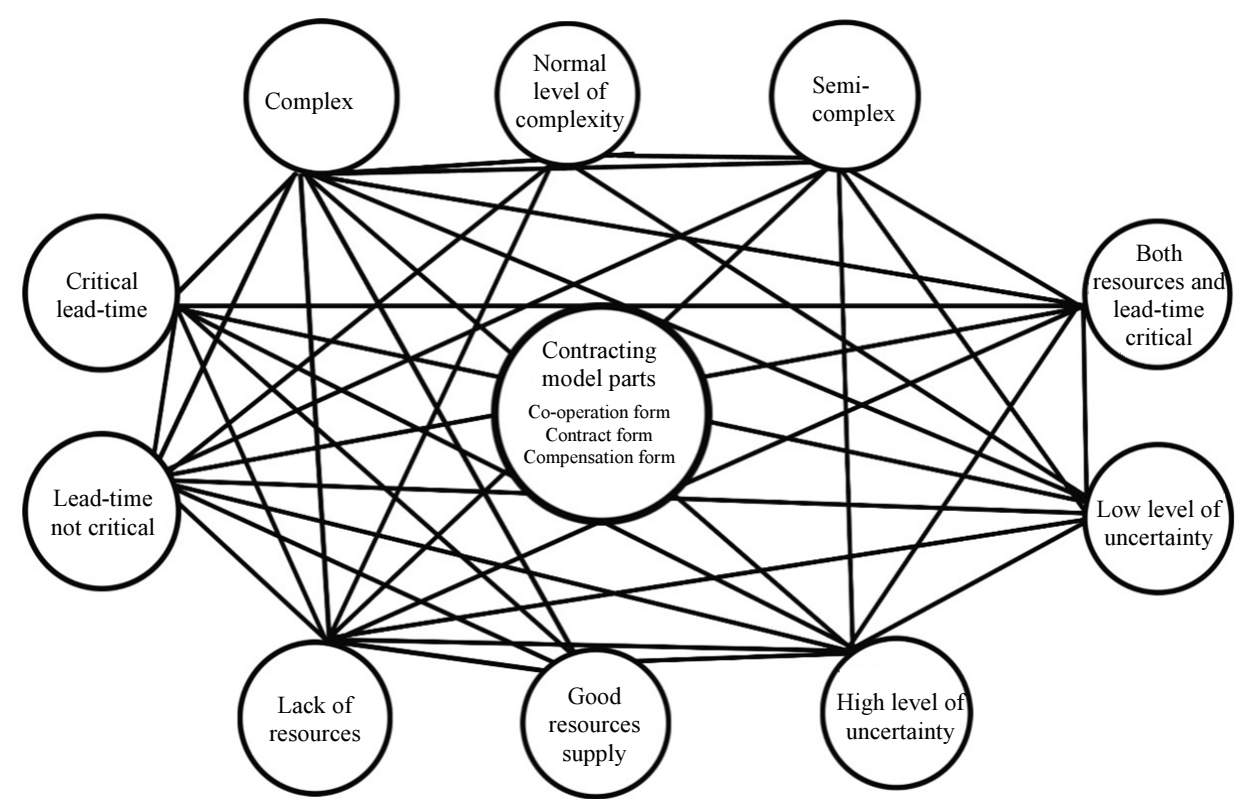

Fig. 2: Questionnaire external and internal factors
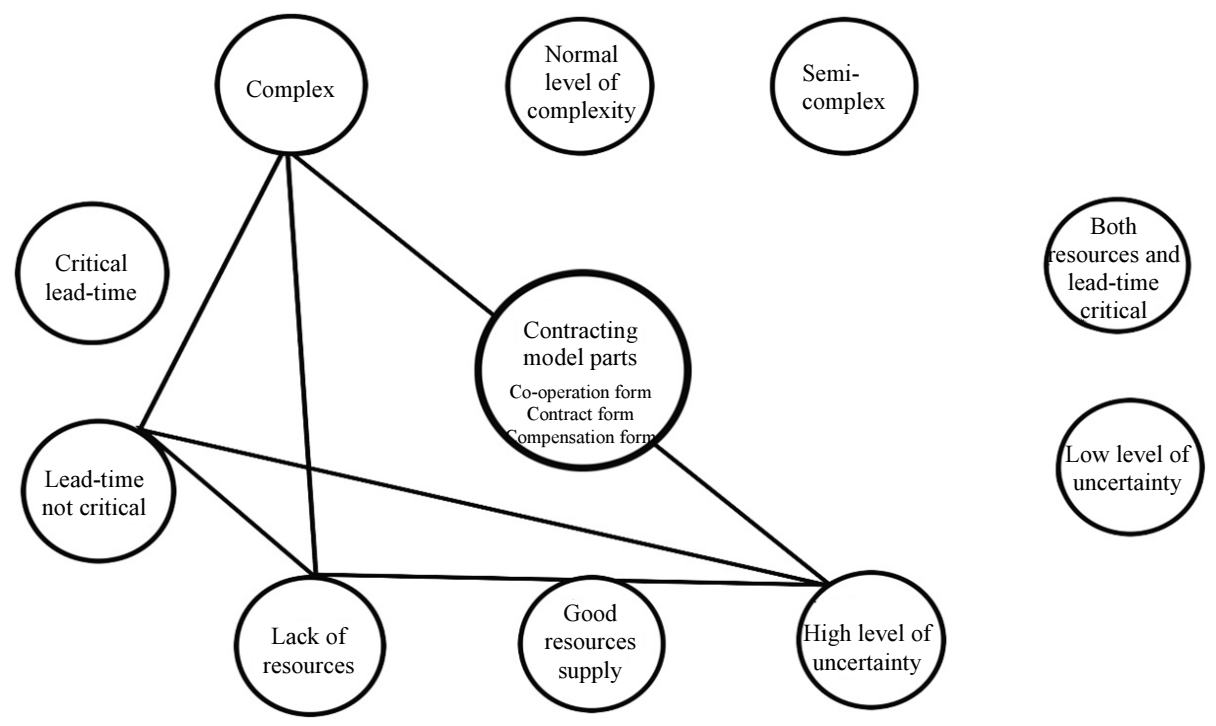

Fig. 3: Illustration of a scenario assumption in the questionnaire

Table 1: Characteristics of different project contexts (Toolanen et al., 2005)

\begin{tabular}{|c|c|c|c|c|c|c|}
\hline \multirow{2}{*}{\multicolumn{2}{|c|}{ Project context }} & \multicolumn{5}{|c|}{ Characteristics } \\
\hline & & \multicolumn{2}{|c|}{ Lead-time } & \multicolumn{2}{|l|}{ Resources } & \multirow[b]{2}{*}{ Uncertain } \\
\hline Abbr. & Description & Slow & Quick & Not critical & Critical & \\
\hline $\mathrm{N}$ & $\begin{array}{l}\text { Normal; design and construction can be time- } \\
\text { wise separated, no lack of bidders }\end{array}$ & $\mathrm{X}$ & & $\mathrm{x}^{*}$ & & \\
\hline $\mathrm{R}$ & $\begin{array}{l}\text { Resources critical; construction and design can be time } \\
\text {-wise separated but there is a risk of lack of bidders }\end{array}$ & $\mathrm{X}$ & & & $\mathrm{x}^{*}$ & \\
\hline $\mathrm{T}$ & $\begin{array}{l}\text { Time critical; short lead-time for design and } \\
\text { construction, but there is no risk of lack of bidders }\end{array}$ & & $\mathrm{X}$ & $\mathrm{x}^{*}$ & & \\
\hline $\mathrm{R} \& \mathrm{~T}$ & $\begin{array}{l}\text { Resources and Time critical; short lead-time for both } \\
\text { design and construction, as well as the risk of lack of bidders }\end{array}$ & & $\mathrm{X}$ & & $\mathrm{x}^{*}$ & \\
\hline $\mathrm{U}$ & Risk for late changes; client interested in promoting innovation & & & & & $\mathrm{X}$ \\
\hline
\end{tabular}


Table 2: Interviewee's main business

\begin{tabular}{ll}
\hline Organization main business & No. of interviewees \\
\hline Contractors (construction) & 12 \\
Consultants (engineering) & 6 \\
Clients & 8 \\
\hline
\end{tabular}

Table 3: The relational contracting projects in Jordan that were considered in the study. BOT-build, operate, transfer; BOO-build-own-operate

\begin{tabular}{ll}
\hline Partnership type & Project title \\
\hline BOT & Queen Alia International Airport \\
BOT & Khribet Al Samra Wastewater Treatment Plant \\
BOT & Al Disi Water Conveyance Project \\
BOO & Mafraq PV IPP project (Renewable Energy) \\
BOO & Amman East Power Plant (Renewable Energy) \\
\hline
\end{tabular}

\section{Results and Discussion}

The aim of the paper is to create a practical project management tool that supports the decision-making process at the concept stage of construction projects in Jordan. Below are the results of the study, summarized in Tables 4 to 7 . Each table (tool) presents results of the different scenarios for the projects, to help with the decision-making of the contract forms based on the Jordanian experience with RC.

"Table 4" indicates that the most recommended contract form in the context of both Normal $(N)$ and Uncertainty $(U)$ is DBB (design-bid-build). DBB is considered to be a preferred, fair and acceptable cooperation form to all project parties. DB (design and build) is considered by the respondents of this research to be the most suitable for the contexts; Resource critical $(R)$, Time Critical $(T)$ and Resource and Time-critical $(R \& T)$. DB is considered to be a short path method to execute the project.

In parallel, the compensation method has almost the same pattern, in that contexts $R, T \& R \& T$ have the same preferred compensation form which is reimbursable cost with incentives (RCI), while Reimbursable Cost has been recommended as the best option under the project contexts $N$ and $U$.

The RCI is a good strategy to share the incentives between the owner and the contractor or consultants and to motivate them to execute the work within the target time and sometimes to save on cost. The Reimbursable Cost method is chosen in the normal project context as fair and acceptable. This method is also preferred in the "uncertainty" context, as the cost in this context might increase with the uncertainty.

A notable finding is that the choice of governance or cooperation from Classical Contracting (CC) and NeoClassical Contracting (NC) are considered to be able to substitute each other in the context $N$. Relational Contracting (RC) and Neo-Classical Contracting (NC) are also considered as substitutes for each other with a slight preference towards $\mathrm{RC}$ in the project context Resource and Time-critical $(R \& T)$. Consequently, $\mathrm{RC}$ is also considered the most recommended option under the context Uncertainty $(U)$.

"Table 5" shows the decision behavior towards the contract model in the typical project (non-complex) with a different project context. This situation is similar, to a great extent, to the one in "Table 4" (the general one for all project types). The notable trend in "Table 5" is the one related to the governance form. The research population has an almost equivalent preference towards the three available cooperation forms in this research, $\mathrm{CC}, \mathrm{NC}$ and $\mathrm{RC}$, when the project time execution is critical. While $\mathrm{CC}$ is a popular choice in the $N$ and $U$ context and secondmost popular with only a slight difference to the most recommended one in both $R \& T$, which makes $C C$ the most preferred choice in almost every project context except $R \& T$. In the context of $R$, both the NC and CC options are substitutes with a slight preference towards the NC form.

As a result, we can conclude that $\mathrm{RC}$ is not a strategic choice when the project is not complex and, depending on the project context, both the NC and CC forms are the main players. Although it offers a high opportunity for project success, RC requires special arrangements and qualifications. Project parties might find that it is not justified to invest in such arrangement and qualification to execute a typical or non-complex project.

"Table 6" demonstrates the choice behavior between the project context and contracting model in a semicomplex project. The choice preference pattern has a lot of compatibility with the one in "Table 4".

The governance form preference in this project type has a unique pattern since the $\mathrm{NC}$ form has been chosen as the most recommended option in all project contexts, although $\mathrm{RC}$ and $\mathrm{CC}$ are considered as a substitute to the NC form in the context $R \& T$. CC could also be considered as a substitute to the $\mathrm{NC}$ form in the context $U$.

With the semi-complex project, project parties find that the semi-flexible method (NC) is the most appropriate to deal with the mild complexity in these kind of projects.

For the first time, Fixed Price (FP) has been selected as the most recommended compensation method in the context $U$. This choice could relate to the contractor's and consultant's desire to limit the owners' room to make future changes to the original scope of work.

"Table 7" indicates that when the project is complex, the interaction between project context and the choice of contracting model is different than those in the noncomplex and semi-complex projects. 
Razan Aleasawi and Sultan Tarawneh / American Journal of Engineering and Applied Sciences 2020, 13 (1): 138.145 DOI: $10.3844 /$ ajeassp.2020.138.145

\begin{tabular}{|c|c|c|c|c|c|c|c|c|c|}
\hline \multirow[b]{3}{*}{ Project context } & \multirow{2}{*}{\multicolumn{2}{|c|}{ Most recommended contract form }} & \multicolumn{4}{|c|}{ Most recommended compensation form } & \multirow{2}{*}{\multicolumn{3}{|c|}{ Most recommended governance form }} \\
\hline & & & & & & & & & \\
\hline & $\begin{array}{l}\text { Construction } \\
\text { Management (CM) }\end{array}$ & $\begin{array}{l}\text { Design-Bid } \\
\text {-Build (DBB) }\end{array}$ & $\begin{array}{l}\text { Design- } \\
\text { Build (DB) }\end{array}$ & $\begin{array}{l}\text { Fixed } \\
\text { Price (FP) }\end{array}$ & $\begin{array}{l}\text { Reimbursable } \\
\text { Cost }\end{array}$ & $\begin{array}{l}\text { Cost with } \\
\text { Incentives (RCI) }\end{array}$ & $\begin{array}{l}\text { Classical } \\
\text { Contracting(CC) }\end{array}$ & $\begin{array}{l}\text { Neo-classical } \\
\text { Contracting (NC) }\end{array}$ & $\begin{array}{l}\text { Relational } \\
\text { Contracting (RC) }\end{array}$ \\
\hline Normal (N) & & $\mathrm{X}$ & & & $\mathrm{X}$ & & $\mathrm{X}$ & $\mathrm{X}$ & \\
\hline Resource critical (R) & & & $\mathrm{x}$ & & & $\mathrm{x}$ & & $\mathrm{x}$ & \\
\hline Time critical (T) & & & $\mathrm{X}$ & & & $\mathrm{X}$ & & $\mathrm{X}$ & \\
\hline Resource and time & & & $\mathrm{x}$ & & & $\mathrm{x}$ & & $\mathrm{x}^{*}$ & \\
\hline critical (R\&T) & & & & $\mathrm{X}$ & & & & & \\
\hline Uncertainty (U) & $\mathrm{x} *$ & $\mathrm{X}$ & & & $\mathrm{x}$ & & & & $\mathrm{X}$ \\
\hline
\end{tabular}

Table 5: Relationship between project context and choosing the contract model (non-complex project)

\begin{tabular}{|c|c|c|c|c|c|c|c|c|c|}
\hline \multirow[b]{3}{*}{ Project context } & \multicolumn{3}{|c|}{ Most recommended contract form } & \multicolumn{3}{|c|}{ Most recommended compensation form } & \multirow{2}{*}{\multicolumn{3}{|c|}{ Most recommended governance form }} \\
\hline & Construction & & & & & Reimbursable & & & \\
\hline & $\begin{array}{l}\text { Management } \\
\text { (CM) }\end{array}$ & $\begin{array}{l}\text { Design-Bid } \\
\text {-Build (DBB) }\end{array}$ & $\begin{array}{l}\text { Design- } \\
\text { Build (DB) }\end{array}$ & $\begin{array}{l}\text { Fixed } \\
\text { Price (FP) }\end{array}$ & $\begin{array}{l}\text { Reimbursable } \\
\text { Costs }\end{array}$ & $\begin{array}{l}\text { Cost with } \\
\text { Incentives (RCI) }\end{array}$ & $\begin{array}{l}\text { Classical } \\
\text { Contracting (CC) }\end{array}$ & $\begin{array}{l}\text { Neo-classical } \\
\text { Contracting (NC) }\end{array}$ & $\begin{array}{l}\text { Relational } \\
\text { Contracting (RC) }\end{array}$ \\
\hline Normal (N) & & $\mathrm{X}$ & & & $\mathrm{X}$ & & $\mathrm{X}$ & & \\
\hline Resource critical (R) & & & $\mathrm{x}$ & & & $\mathrm{x}$ & $\mathrm{x}^{*}$ & $\mathrm{X}$ & \\
\hline Time critical (T) & & & $\mathrm{x}$ & & & $\mathrm{X}$ & $\mathrm{x}^{*}$ & $\mathrm{X}$ & $\mathrm{X}$ \\
\hline $\begin{array}{l}\text { Resource and time } \\
\text { critical (R\&T) }\end{array}$ & & & $\mathrm{x}$ & & & $\mathrm{x}$ & & $\mathrm{x}$ & \\
\hline Uncertainty (U) & $\mathrm{X}$ & & & & $\mathrm{x}$ & & $\mathrm{X}$ & & \\
\hline
\end{tabular}

Table 6: Relationship between project context and choosing the contract model-(semi-complex project)

\begin{tabular}{|c|c|c|c|c|c|c|c|c|c|}
\hline \multirow[b]{3}{*}{ Project context } & \multicolumn{3}{|c|}{ Most recommended contract form } & \multicolumn{3}{|c|}{ Most recommended compensation form } & \multirow{2}{*}{\multicolumn{3}{|c|}{ Most recommended governance form }} \\
\hline & Construction & & & & & Reimbursable & & & \\
\hline & $\begin{array}{l}\text { Management } \\
\text { (CM) }\end{array}$ & $\begin{array}{l}\text { Design-Bid- } \\
\text { Build (DBB) }\end{array}$ & $\begin{array}{l}\text { Design- } \\
\text { Build (DB) }\end{array}$ & $\begin{array}{l}\text { Fixed } \\
\text { Price (FP) }\end{array}$ & $\begin{array}{l}\text { Reimbursable } \\
\text { Costs }\end{array}$ & $\begin{array}{l}\text { Cost with } \\
\text { Incentives (RCI) }\end{array}$ & $\begin{array}{l}\text { Classical } \\
\text { Contracting (CC) }\end{array}$ & $\begin{array}{l}\text { Neo-classical } \\
\text { Contracting (NC) }\end{array}$ & $\begin{array}{l}\text { Relational } \\
\text { Contracting (RC) }\end{array}$ \\
\hline Normal (N) & & $\mathrm{X}$ & & & $\mathrm{X}$ & & & $\mathrm{X}$ & \\
\hline Resource critical (R) & & & $\mathrm{X}$ & & & $\mathrm{x}$ & & $\mathrm{X}$ & \\
\hline Time critical (T) & & & $\mathrm{X}$ & & & $\mathrm{X}$ & & $\mathrm{X}$ & \\
\hline $\begin{array}{l}\text { Resource and time } \\
\text { critical (R\&T) }\end{array}$ & & & $\mathrm{X}$ & & & $\mathrm{x}$ & $\mathrm{X}$ & $\mathrm{X}$ & $\mathrm{X}$ \\
\hline Uncertainty (U) & $\mathrm{X}$ & & & $\mathrm{X}$ & & & $\mathrm{x}^{*}$ & $\mathrm{X}$ & \\
\hline
\end{tabular}

\begin{tabular}{|c|c|c|c|c|c|c|c|c|c|}
\hline \multirow[b]{3}{*}{ Project context } & \multicolumn{3}{|c|}{ Most recommended contract form } & \multicolumn{3}{|c|}{ Most recommended compensation form } & \multirow{2}{*}{\multicolumn{3}{|c|}{ Most recommended governance form }} \\
\hline & \multirow{2}{*}{$\begin{array}{l}\text { Construction } \\
\text { Management } \\
\text { (CM) }\end{array}$} & \multirow[b]{2}{*}{$\begin{array}{l}\text { Design-Bid } \\
\text {-Build (DBB) }\end{array}$} & \multirow[b]{2}{*}{$\begin{array}{l}\text { Design- } \\
\text { Build (DB) }\end{array}$} & \multirow[b]{2}{*}{$\begin{array}{l}\text { Fixed } \\
\text { Price (FP) }\end{array}$} & \multirow[b]{2}{*}{$\begin{array}{l}\text { Reimbursable } \\
\text { Costs }\end{array}$} & \multirow{2}{*}{$\begin{array}{l}\text { Reimbursable } \\
\text { Cost with } \\
\text { Incentives (RCI) }\end{array}$} & & & \\
\hline & & & & & & & $\begin{array}{l}\text { Classical } \\
\text { Contracting (CC) }\end{array}$ & $\begin{array}{l}\text { Neo-classical } \\
\text { Contracting (NC) }\end{array}$ & $\begin{array}{l}\text { Relational } \\
\text { Contracting (RC) }\end{array}$ \\
\hline Normal (N) & & $\mathrm{X}$ & & & $\mathrm{X}$ & & $\mathrm{X}$ & & \\
\hline Resource critical (R) & & $\mathrm{x}$ & & & & $\mathrm{X}$ & & & $\mathrm{X}$ \\
\hline Time critical (T) & & & $\mathrm{x}$ & & & $\mathrm{X}$ & & $\mathrm{X}$ & \\
\hline Resource and time & & & & & & & & & \\
\hline critical (R\&T) & & & $\mathrm{X}$ & & & $\mathrm{X}$ & & & $\mathrm{X}$ \\
\hline Uncertainty (U) & & $\mathrm{X}$ & & & & $\mathrm{x}$ & & & $\mathrm{X}$ \\
\hline
\end{tabular}

$\mathrm{x}^{*}$ : Second best choice with a slight difference compared to the most recommended one

The most recommended contract form varies depending on the project context. In the context $N, R$ and $U, \mathrm{DBB}$ is recommended, while DB is recommended in the context $T$ and $R \& T$. The choice of DB under the condition of short lead-time may be due to the ability of this form to shorten the time required to execute the project by completing the concept design during the project execution. DBB is preferred in all project types under the context $N$, as this form looks fair and less costly compared to other forms. In the context $R$, the DBB form is preferred by the contractors and consultants as they enjoy a high level of demand for their services in the market. This form is considered to be short-term compared to the others. The DBB form is also picked as the desired one in the context $U$ as completing the full design prior to the execution of work could limit possible future changes to the original scope of work.

$\mathrm{RCI}$ is the most popular method for complex projects as it is recommended in every project context except $N$, where the Reimbursable Costs was considered the best choice. The incentives in the RCI form are desired to share the risks and benefits and this would lead to a better and more efficient execution of work.

The recommendation of $\mathrm{RC}$ in this project type is notable as well, since it has been recommended in the context $R, R \& T$ and $U$, while also being recommended as a substitute to $\mathrm{CC}$ in the context $T$ and both are regarded as the second-best option. The $\mathrm{NC}$ form has been recommended only in the context $T$.

$\mathrm{RC}$ as a cooperation form is able to deal with a high level of risk, especially if the project itself is complex. This explains why the respondents did not choose RC when the project context is $N$, since the project is considered nonrisky. The best, most cost and time saving option is the $\mathrm{CC}$ form. This form does not require any special arrangement or special human resources skills.

When the project is complex and has a critical time to finish it, RC is not the optimal situation as it is considered time consuming during the bidding stage. This stage could range from a few months to a year or 
more in some very complicated projects. Therefore, the project parties prefer NC as a flexible form to deal with complex projects with a short lead-times.

$\mathrm{RC}$ is preferred for complex projects with critical resource contexts. $R$ has a high level of project risk and applying RC will transfer and limit the risk, as the project consortium is now responsible for finding the capable contractors and consultants to execute the work. The same is applied in the context of both $R$ and $T$. Although this context is time critical, respondents see that the combination of both time critical and resources critical could be better met by partnering. Within that, the resource critical aspect could become time-consuming if the project owner finds it difficult to find the required contractors to execute such a complex project.

$\mathrm{RC}$ is the desired cooperation strategy when the project is complex and where there might be a high possibility to change the project requirement during the execution period, especially in high specialty projects which are highly affected by changes in technology. RC transfers this risk to the party or parties who can better deal with it.

\section{Conclusion}

The results gained from this inquiry shows that the project context has a significant impact on the procurement model. The prerequisites considered in the inquiry are; project type (typical, semi-complex and complex), market situation for bidding, lead-time for project delivery and uncertainties (the risk of changing the design and/or requirements in the late stages of project execution). The research also shows that the contracting model has three significant interacting components; the contract form (distribution of responsibilities), compensation form (how the contractor(s) is compensated) and governance structure (how the project is administrated and organized).

This study found that RC is recommended in Jordan for complex projects, under the characteristics of resourcescritical, resources and time-critical and with uncertainties. This supports the TCE theory that concentrates on the costs included in making transactions instead of producing products and suggests vertical integration to avoid that cost. This study recommends that future work use a case study approach and focus group discussion for data collection. Additionally, the focus should be on other factors that may affect the selection process of contractual models as well as studying the relationship between these factors and the performance of RC projects.

It is highly recommended to conduct a survey using a large population, including respondents who do and do not have experience with $\mathrm{RC}$ projects, to measure the level of awareness toward these types of projects. This will also help to understand what is missing in the Jordanian construction industry, regarding improving RC implementation and investigate motivators and barriers other than market requirements.

\section{Appendix A. Acronyms}

Table A1: Acronyms

\begin{tabular}{ll}
\hline Acronyms & Full Discerption \\
\hline PPP & Public-Private-Partnerships \\
NC & Neo-classical Contracting \\
CM & Construction Management \\
RC & Relational Contracting \\
RCI & Reimbursable Cost with Incentives \\
FP & Fixed Price \\
DBB & Design-Bid-Built \\
DB & Design-Build \\
CC & Classical Contracting \\
R & Resources critical \\
R\&T & Resources and Time critical \\
U & Uncertainty \\
T & Time critical \\
\hline
\end{tabular}

\section{Acknowledgement}

I would like also to express my sincere appreciation to all contractors who took a part in this research. Many thanks to the companies project managers for their time and effort to provide valuable information.

\section{Author's Contributions}

This paper is extracted from a master thesis prepared by Razan Aleasawi, which was conducted under the supervision of Prof. Sultan Tarawneh. While Razan conducted the literature review, data collection and analyzing it and prof. Sultan reviewed the work and provided all the guidance and comments needed to accomplish this research. Thus the final paper is the result of the two author's collaboration.

\section{Ethics}

Both authors confirm that this work has not been submitted to any other journal and there are no consequences in publishing it.

\section{References}

Abbasi, G., M. Abdel-Jaber and A. Abu-Khadejeh, 2005. Risk analysis for the major factors affecting the construction industry in Jordan. Emirates J. Eng. Res., 10: 41-47.

Al-Hazim, N., Z. Abu Salem and H. Ahmad, 2017. Delay and cost overrun in infrastructure projects in Jordan. Proceedings of the 7th International Conference on Engineering, Project and Production Management, (PPM' 17), Elsevier Ltd, pp: 18-24. DOI: 10.5539/ijbm.v9n2p124

Al-Shqairat, Z.I., A.E. AL Shra'ah, M.I. Al-rawad and M.H. Al-Kilani, 2014. Assessing the planning of Public Private Partnership (PPP) in E-Government implementation experience in Jordan. Int. J. Bus. Manage., 9: 124-134. DOI: 10.5539/ijbm.v9n2p124 
Campbell, D. and D. Harris, 2005. Flexibility in longterm contractual relationships: The role of cooperation. Lean Construct. J., 2: 5-29. DOI: $10.2307 / 1410166$

Council, T. E., 2017. Jordan Economic Growth Plan 2018 - 2022. Amman, Jordan.

DS, 2013. Jordan statistical yearbook Hashemite Kingdom of Jordan. Amman, Jordan.

Faisol, N., A.R.J. Dainty and A.D.F. Price, 2005. The concept of 'relational contracting' as a tool for understanding inter-organizational relationships in construction. Proceedings of the $21 \mathrm{st}$ Annual Association of Researchers in Construction Management, (RCM' 05), pp: 1075-1084.

Jamali, D., 2004. Success and failure mechanisms of Public Private Partnerships (PPPs) in developing countries: Insights from the Lebanese context. Int. J. Public Sector Manage., 17: 414-430.

DOI: $10.1108 / 09513550410546598$

Kwawu, W., W. Hughes, 2005. The impact of relational contracting on the construction industry. University of London. Association of Researchers in Construction Management, 2: 1195-204.

MacNeil, I.R., 1974. Restatement (Second) of contracts and presentation. Virginia Law Rev., 60: 589-610.

MacNeil, I.R., 1978. Contracts: Adjustment of long-term economic relations under classical, neoclassical and relational contract law. Northwestern University Law Rev., 72: 854-905.

DOI: $10.4236 /$ ajibm.2015.55031
MacNeil, I.R., 1980. The new social contract: an inquiry into modern contractual relations. 1st Edn., Yale University Press, New Haven, ISBN-10: 0300025424, pp: 164.

Ministry of Municipal Affairs, 2014. Municipalities Public-Private Partnerships (PPP) and investment guide. Amman.

Palaneeswaran, E., M. Kumaraswamy, M.M. Rahman and T. Ng, 2003. Curing congenital construction industry disorders through relationally integrated supply chains. Build. Environ., 38: 571-582. DOI: $10.1016 / \mathrm{S} 0360-1323(02) 00188-9$

Rahman, M.M. and M.M. Kumaraswamy, 2004. Contracting relationship trends and transitions. J. Manage. Eng., 20: 147-161. DOI: $10.1080 / 01446190110089682$

Sawalha, M., 2015. Public-private partnership in Jordan. UAE, Sharjah.

Toolanen, B., T. Olofsson and J. Johansson, 2005. Transparency and cooperation-essential factors of lean contracting. Lean Supply Chain Manage.

Williamson, O.E., 1979. Transaction-cost economics: The governance of contractual relations. J. Law Econo., 22: 233-261.

Williamson, O.E., 1985. The Economic Institutions of Capitalism: Firms, Markets and Relational Contracting. 1st Edn., Simon and Schuster, ISBN-10: 068486374X, pp: 450. 